\title{
Removal of residual yolk at hatch influences food choice and feeding activity in lines of chickens selected for high or low juvenile body weight
}

\author{
I Turro-Vincent 1 , Z Nitsan ${ }^{3}, \mathrm{M}$ Picard ${ }^{1 *}$, \\ EA Dunnington ${ }^{2}$, PB Siegel 2
}

1 INRA, Station de Recherches Avicoles, Centre de Tours-Nouzilly, 37380 Nouzilly, France;
2 Animal and Poultry Sciences Department, Virginia Polytechnic Institute
and State University, Blacksburg, VA 24061, USA;
${ }^{3}$ Agricultural Research Organization, The Volcani Center, 50250 Bet Dagan, Israel

(Received 16 March 1994; accepted 18 July 1994)

\begin{abstract}
Summary - The effect of residual yolk removal at hatch on growth and feeding behavior was assessed in lines of chickens divergently selected for low (LW) or high (HW) 56-day body weight. At hatch chicks were assigned to 1 treatment: removal of the residual yolk $(R)$ or no surgery $(I)$. Twenty-four chicks per line (12 I and $12 \mathrm{R}$ ) were assigned to an all-mash regimen (M) and 48 per line ( $24 \mathrm{I}$ and $24 \mathrm{R}$ ) to a choice (C) between mash and dietary residual yolk. HW were heavier than LW chicks regardless of treatment. On day 5 and thereafter, chicks given a choice were heavier than those eating mash. HW chicks ate more than LW ones. The percentage of yolk eaten increased during the 2-3 $\mathrm{d}$ after hatch, remained constant for $2 \mathrm{~d}$, then decreased. Results are discussed in term of yolk need and development of the gastrointestinal tract in the divergent lines.
\end{abstract}

genetic line / vitellus / deutectomy / feeding behavior / activity / growth

Résumé - Le retrait du résidu vitellin à l'éclosion influence les choix et le comportement alimentaire chez des lignées de poulets sélectionnées pour un poids corporel juvénile fort ou faible. L'effet de la deutectomie à l'éclosion sur la croissance et le comportement alimentaire a été testé sur des lignées de poulets sélectionnées pour un poids corporel fort (HW) ou faible (LW) à $56 \mathrm{j}$. $\dot{A}$ l'éclosion, les poussins sont vitellectomisés $(R)$ ou non traités (I). Vingt-quatre poussins par lignée (121 et $12 R$ ) reçoivent un aliment farine $(M)$ et 48 par lignée (24I) et $24 R$ ) ont le choix entre l'aliment farine et du résidu vitellin. Les poussins HW sont plus lourds que les $L W$, quel que soit le traitement. À partir du $5^{e} j$, les poussins en choix sont plus lourds que ceux qui ne consomment que de la farine. Les HW consomment plus que les $L W$. Le pourcentage de résidu vitellin consommé augmente pendant les 2 à 3 j qui suivent l'éclosion, reste constant pendant 2 j puis diminue. Les résultats sont discutés en termes de besoin en vitellus et développement du tractus gastro-intestinal chez ces lignées divergentes.

lignée / vitellus / deutectomie / comportement alimentaire / activité / croissance

* Correspondence and reprints 


\section{INTRODUCTION}

Free choice feeding tests are commonly used to ascertain how birds select and balance their diet. Several studies have shown that domestic chickens can self-select an adequate ratio of protein and energy (eg, Kaufman et al, 1978; Brody et al, 1983; Sinurat and Balnave, 1986; Rose and Kyriakis, 1991). The ratios, however, may be stockspecific. When chicks from lines of White Plymouth Rocks selected for high or low body weight at 56 days of age (Dunnington and Siegel, 1985) were subjected to free choice feeding, high-line chickens chose diets higher in protein and lower in energy, while low-line chickens preferred lower protein and higher energy diets (Huey et al, 1982). Similarly, a genetically fat line of chickens preferred a lower protein diet than one selected for lean (Leclercq and Guy, 1991).

Residual yolk may serve as a source of nutrients during the first few days after hatch (Murakami et al, 1988; Nir et al, 1988; Nitsan et al, 1991), a period when the young chick shifts from endogenous to exogenous nutrition. Murakami et al (1992) showed that removal of residual yolk at hatch delayed growth by $2 \mathrm{~d}$. Residual yolk did not influence the rate of nutrient utilization or vice versa, and they suggested that yolk may be transported via circulation rather than through the yolk stalk which is consistent with empirical data obtained by Nitsan et al (personal communication).

Lines of chickens selected for high or low juvenile body weight (Dunnington and Siegel, 1985) differed in feeding behavior and food intake (Barbato et al, 1980; Dunnington et al, 1987; Boa Amponsen et al, 1991; O'Sullivan et al, 1992a; Noble et al, 1993). These lines did not react in the same way to removal of the yolk sac at hatch (Turro et al, 1994), suggesting a need for further study of utility of residual yolk and interactions between digestive tract devel- opment and yolk resorption. Chamblee et al (1992) fed diets with different levels of fat to broiler chicks whose yolk sacs were removed. They reported that dietary fat has its greatest effect on growth $10 \mathrm{~d}$ after hatch and that initiation of growth may be more heavily dependent upon other nutrients. The experiment reported in this paper investigated the effect of removal of residual yolk at hatch on growth and feeding behavior of chicks from lines divergently selected for 56-day body weight when presented with a feeding choice between a complete starter diet and dried residual yolk.

\section{MATERIALS AND METHODS}

\section{Stocks, husbandry procedures and experimental procedures}

The chicks used in this experiment were White Plymouth Rocks chicks from the 36th generation of lines selected for a high (HW) or low (LW) body weight at $56 \mathrm{~d}$ of age (Dunnington and Siegel, 1985). Chicks from each line were removed from the hatcher, wingbanded, and weighed to the nearest $0.1 \mathrm{~g}$. Seventy-two chicks were then randomly assigned for either removal of the yolk sac $(R)$ or to remain intact (I). Body weights of $R$ chicks were also obtained to the nearest $0.1 \mathrm{~g}$ after removal of the yolk sac. The procedure for removal of the yolk sac has been described previously (Turro et al, 1994). Briefly, each chick was anesthetized and a small incision made posterior to the umbilicus. The yolk sac was removed from the abdominal cavity and the yolk stalk was tied and severed from the yolk sac. Recovery was made within $30 \mathrm{~min}$ and mortality nil. Within $4 \mathrm{~h}$ of the beginning of surgery all chicks had been randomly assigned and placed in 36 wirefloor pens in an electrically heated battery with 4 chicks per pen. Within each line chicks were randomly assigned to an all-mash (M) diet (3 146 $\mathrm{kcal} / \mathrm{kg} \mathrm{ME}, 24 \%$ protein) or a choice (C) between mash and residual yolk (4 $953 \mathrm{kcal} / \mathrm{kg}, 51 \%$ protein). Twenty-four chicks per line (12 I and $12 \mathrm{R}$ ) were assigned to the $M$ regimen and 48 per line ( $24 \mathrm{I}$ and $24 \mathrm{R}$ ) were assigned to the $\mathrm{C}$ regimen. 
Lines (HW, LW) and treatments (IM, IC, RM, RC) were not intermingled in the same pens.

Food and water were always available and lighting was continuous. Chicks and feeders were individually weighed to the nearest gram each day with total intake of metabolizable energy and of protein calculated for each group. The number of chicks eating, drinking, standing, or resting was recorded for each pen at 07.00, 07.30, $09.00,09.30,13.00,13.30,17.00$ and $17.30 \mathrm{~h}$ as described by Turro et al (1994). With choice feeding, the type of feed being eaten was recorded.

At $7 \mathrm{~d}$ of age, 2 chicks from each pen were randomly selected and blood was obtained for determination of plasma glucose and lipid. Glucose was measured by the oxidase method (Hestin-Lerner and Ben Yonah, 1963) and total lipids were measured according to the method of Zoellner and Kirsch (1962). Residual yolk, heart, liver, pancreas and small intestine were removed from these chickens and weighed to the nearest $0.01 \mathrm{~g}$. The chyme (contents of the small intestine) was removed and the weight determined as the difference between the full and empty small intestine. Total fat was extracted by chloroform methanol $(2: 1)$ from liver and from residual yolk by the method of Folch et al (1957). Liver, yolk, and blood protein were measured by Biuret reactions using Sigma Diagnostics Total Protein Reagent Procedure No 541 (Sigma Diagnostics, Saint Louis, MO 63178).

\section{Statistical analysis}

Prior to analyses, body and absolute organ weights were transformed into common logarithms and ratios to arcsine square roots. Behavioral data were averaged for the two 30-min periods at each time and transformed to the arcsine square root of the ratio of chicks exhibiting each behavior.

Analyses of variance were conducted separately for each day for behaviors, feed intake, and body weight. Line, treatment, and time of day were main effects for behavioral data, and line and treatment were main effects for food intake and body weights. Organs, blood lipids, glucose, and protein data were analyzed with line and treatment as main effects. When interactions were significant, comparisons of multiple means were made by Duncan's multiple range test within each main effect.

\section{RESULTS}

\section{Growth and food intake}

\section{Growth}

Interactions of line by treatment were significant for body weight at 2 and $3 \mathrm{~d}$, but not at 1, 4, 5, 6 and $7 \mathrm{~d}$ after hatch. HW chicks were heavier than $L W$ chicks regardless of treatment (fig 1), while differences among treatments within lines differed on days 2 and 3 . The IC and $\mathrm{IM}$ chicks were heavier than RC and RM chicks in line HW, while in line LW, IM and RC chicks did not differ, causing the interaction. In both lines and in each treatment, there was a trend for chicks given a choice of mash or yolk to be heavier than those eating mash only with the cumulative effect being that the difference were significant on $\mathrm{d} 5$ and thereafter.

Weight gains from hatch to 4 and $7 \mathrm{~d}$ after hatch were less for LW than HW chicks (table I) with the line-by-treatment interaction significant for both time periods. In the LW

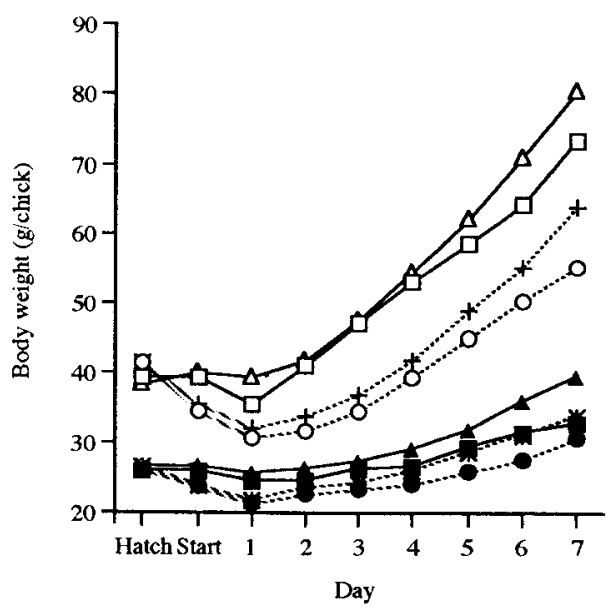

Fig 1. Body weight of chicks ( $g /$ chick) by line (LW or $\mathrm{HW})$, with or without removal of the yolk sac $(\mathrm{R}$, I), eating mash or mash and yolk $(M, C)$. - LW I M; - A- LW I C; - $\square-\mathrm{HW}$ I M; $-\Delta-$ HW I C; ------ LW R M; -...*-- LW R C; --.O--. HW R M; ---+-- HW R C. 
Table I. Body weight gains ( $\mathrm{g} / \mathrm{chick}$ ) of chicks by line and treatment at 4 and $7 \mathrm{~d}$ after hatch.

\begin{tabular}{lccccc} 
Treatment & \multicolumn{2}{c}{ Gain $0-4$} & & \multicolumn{2}{c}{ Gain $0-7$} \\
\cline { 5 - 6 } & $H W$ & $L W$ & $H W$ & $L W$ \\
\hline Intact choice & & & & & \\
Intact mash & $14.5^{\mathrm{a}}$ & $2.6^{\mathrm{a}}$ & & $40.3^{\mathrm{a}}$ & $12.7^{\mathrm{a}}$ \\
Yolk removed choice & $13.9^{\mathrm{a}}$ & $0.9^{\mathrm{a}}$ & & $34.0^{\mathrm{ab}}$ & $7.2^{\mathrm{b}}$ \\
Yolk removed mash & $6.2^{\mathrm{b}}$ & $1.5^{\mathrm{a}}$ & & $28.7^{\mathrm{bc}}$ & $9.9^{\mathrm{b}}$ \\
& $4.4^{\mathrm{b}}$ & $0.6^{\mathrm{a}}$ & & $19.8^{\mathrm{c}}$ & $7.0^{\mathrm{b}}$
\end{tabular}

Means in a column with the same superscript were not significantly different. Differences between lines are always significant $(P<0.01)$.

line, body weight gains were similar among treatments to $4 \mathrm{~d}$, while in line $\mathrm{HW}$, the IC and IM chicks gained more weight than RC and $\mathrm{RM}$ chicks (14.2 vs 5.3\%). By $7 \mathrm{~d}$, the gain of IC chicks from line LW was greater than that for the 3 other groups (12.7 vs $8.0 \%$ ), while for HW chicks the gain was greater for IC than for RC and RM which did not differ.

\section{Food intake}

There was no line-by-treatment interaction for food intake on any day for chicks provided with choice feeding. HW chicks consistently ate more than LW chicks with differences being significant on days 2, 3, 5, 6 and 7 (fig 2a). There were no differences between I and $R$ chicks for feed intake (fig $2 b)$. For groups eating only mash, commencing on day 2 , the consumption of I chicks from line HW was consistently greater than that for all other groups with differences significant on days 4, 5 and 6 (fig 3a).

There were no line-by-treatment interactions for percentage yolk consumed in choice feeding on any day. The percentage yolk consumed was low on day 1 , it increased during the first 2 to $3 \mathrm{~d}$ after hatch, remained relatively constant for about $2 \mathrm{~d}$, and then decreased (fig $3 b$ ).

\section{Nutrient intake}

Due to the differences existing in nutritive values between mash and residual yolk, the total protein intake and energy intake of chicks for each treatment were calculated from hatch to $7 \mathrm{~d}$ of age (tables II and III). The following comments are based on calculated values using $3.146 \mathrm{cal}$ and $0.24 \mathrm{~g}$ protein for $1 \mathrm{~g}$ mash and $4.953 \mathrm{cal}$ and $0.51 \mathrm{~g}$ protein for $1 \mathrm{~g}$ yolk.

\section{Metabolisable energy and protein intake}

HW chicks consumed more ME and protein than LW (tables II and III). Treatment tended to affect the ME and protein intake ( $P=$ $0.08)$. $P$ values for line-by-treatment and line-by-regimen ranged from 0.10 to 0.16 . They reflected that vitellectomy reduces the energy and protein intake of HW but not LW chicks with choice.

Regimen ( $\mathrm{M}, \mathrm{C})$ did not have a significant effect on protein and energy intake, but tended to modify the responses of the 2 lines. HW chicks tended to increase protein and energy intake from a mash diet to a choice of mash and yolk. In the same situation, LW chickens tended to decrease their energy intake and to maintain protein consumption. 


\section{Behavior}

Analyses of variance were conducted for behaviors separately for each day. Only 7 of 140 first- and second-order interactions were significant. There was no consistent pattern and we attribute them to chance. For eating, there were no treatment effects, how-
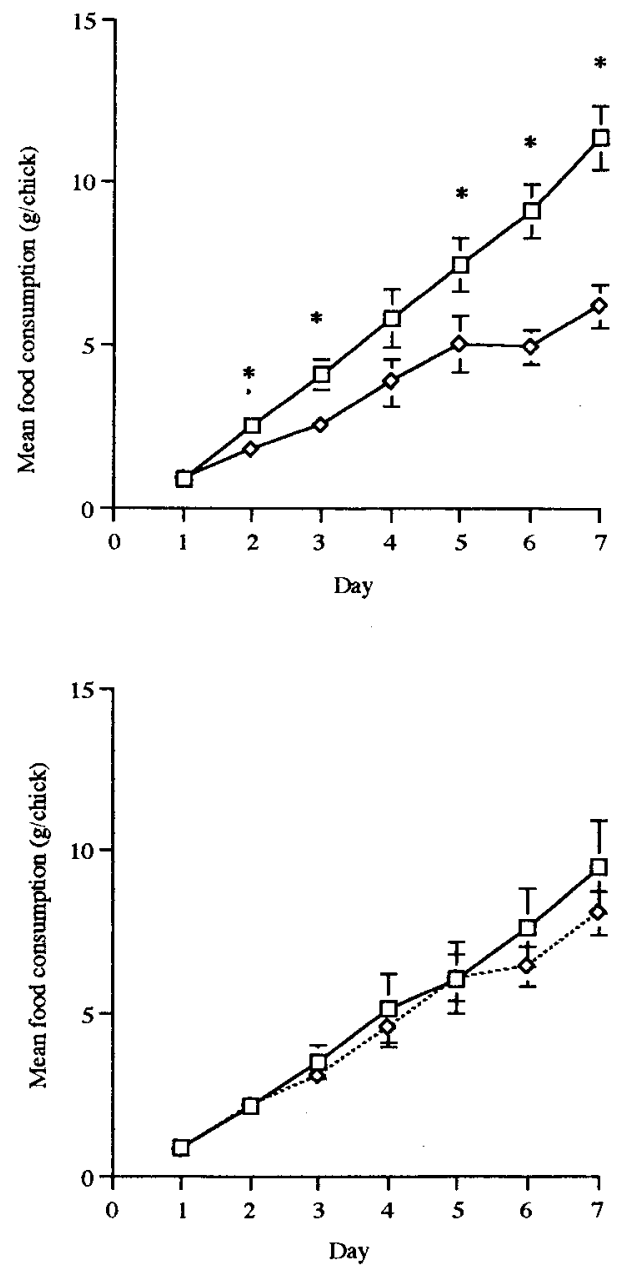

Fig 2. Total food intake (choice group) by line (top) or treatment (bottom) during the first week of life. * $P<0.05$. Top: $\square \mathrm{HW} ; \bigcirc \mathrm{LW}$; bottom: $\square$ intact; $\diamond$ removed. ever time of day effects were significant on days 3 and 6 . On day 3 the percentage of chicks eating mash at $17.00 \mathrm{~h}(6.2 \%)$ was greater than at other times $(0.5 \%)$. On day 6 the percentages were $2.1,7.8,1.6$ and $8.7 \%$ for $07.00,09.00,13.00$ and $17.00 \mathrm{~h}$, respectively, with 7.8 and $8.7 \%$ different from the 2.1 and $1.6 \%$. On day 6 the per-
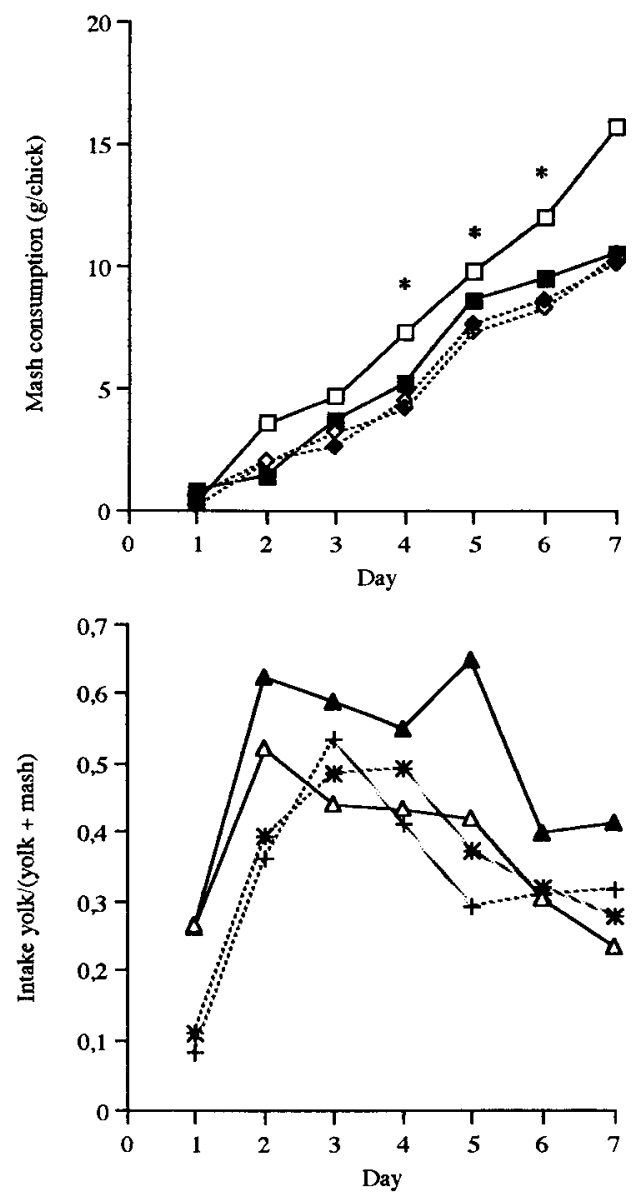

Fig 3. Mean mash consumption during the first week of life of the control chicks $\left.{ }^{*} P<0.05\right)$ (top) and ratio of yolk eaten in the choice group (bottom). Top: - $\square-\mathrm{HWl}$; --- - -- HWR; - LWI; --- --- LWR; bottom: $-\Delta-\mathrm{HW}$ I C; ---+-HW R C; - $\Delta-$ LWIC; -..*-.. LW R C. 
Table H. Calculated energy (cal/chick) and protein intake ( $\mathrm{g} / \mathrm{chick}$ ) and food intake ( $\mathrm{g} / \mathrm{chick}$ ) (means \pm SEM) from hatch to $7 \mathrm{~d}$ of age.

\begin{tabular}{|c|c|c|c|c|c|c|c|}
\hline \multirow[t]{2}{*}{ Treatment } & \multicolumn{2}{|c|}{ Metabolisable energy } & \multicolumn{2}{|c|}{ Crude protein } & \multicolumn{3}{|c|}{ Food intake } \\
\hline & Mash & Choice & Mash & Choice & Mash & $\begin{array}{c}\text { Chd } \\
\text { Mash }\end{array}$ & $\begin{array}{l}\text { ice } \\
\text { Yolk }\end{array}$ \\
\hline \multicolumn{8}{|l|}{$H W$} \\
\hline Intact & $\begin{array}{r}167.0 \\
\pm 6.0\end{array}$ & $\begin{array}{r}171.5 \\
\pm 24.7\end{array}$ & $\begin{array}{r}12.7 \\
\pm 0.5\end{array}$ & $\begin{array}{r}14.9 \\
\pm 2.1\end{array}$ & $\begin{array}{r}53.1 \\
\pm 1.9\end{array}$ & $\begin{array}{r}32.7 \\
\pm 5.7\end{array}$ & $\begin{array}{r}13.9 \\
\pm 1.6\end{array}$ \\
\hline Yolk removed & $\begin{array}{r}111.5 \\
\pm 18.8\end{array}$ & $\begin{array}{r}135.6 \\
\pm 8.4\end{array}$ & $\begin{array}{r}8.5 \\
\pm 1.4\end{array}$ & $\begin{array}{r}11.9 \\
\pm 0.6\end{array}$ & $\begin{array}{r}35.4 \\
\pm 6.0\end{array}$ & $\begin{array}{r}24.4 \\
\pm 3.1\end{array}$ & $\begin{array}{r}11.9 \\
\pm 0.7\end{array}$ \\
\hline \multicolumn{8}{|l|}{$L W$} \\
\hline Intact & $\begin{array}{r}124.0 \\
\pm 12.1\end{array}$ & $\begin{array}{r}90.8 \\
+17.2\end{array}$ & $\begin{array}{r}9.5 \\
\pm 0.9\end{array}$ & $\begin{array}{r}8.2 \\
\pm 1.4\end{array}$ & $\begin{array}{r}39.4 \\
\pm 3.8\end{array}$ & $\begin{array}{r}14.0 \\
\pm 4.9\end{array}$ & $\begin{array}{r}9.4 \\
+0.5\end{array}$ \\
\hline Yolk removed & $\begin{array}{r}112.5 \\
\pm 13.8\end{array}$ & $\begin{array}{r}99.7 \\
+11.1\end{array}$ & $\begin{array}{r}8.6 \\
+1.1\end{array}$ & $\begin{array}{r}8.7 \\
\pm 0.9\end{array}$ & $\begin{array}{r}35.7 \\
\pm 4.4\end{array}$ & $\begin{array}{r}18.8 \\
\pm 3.8\end{array}$ & $\begin{array}{r}8.2 \\
\pm 0.9\end{array}$ \\
\hline
\end{tabular}

Table III. Anova of the results presented in table II.

$\begin{array}{lll} & \begin{array}{c}\text { Anova: main effects } \\ \text { and interactions }\end{array} \\ & \begin{array}{c}\text { Metabolisable } \\ \text { energy }\end{array} & \begin{array}{c}\text { Crude } \\ \text { protein }\end{array} \\ & & \\ \text { Line } & P<0.01 & P<0.01 \\ \text { Treatment } & P=0.08 & P=0.08 \\ \text { Regimen } & P=0.74 & P=0.30 \\ \text { Line } x \text { treatment } & P=0.10 & P=0.11 \\ \text { Line } x \text { regimen } & P=0.16 & P=0.11 \\ \text { Treatment } x \text { regimen } & P=0.44 & P=0.53 \\ \text { Line } x \text { treatment } x \text { regimen } P=0.99 & P=0.97\end{array}$

centage of HW chicks eating mash was greater than that for LW chicks (7.0 vs $3.0 \%)$ with the percentage similar for those eating yolk (1.3 vs $1.7 \%)$.

During the total time of the experiment, $\mathrm{HW}$ chicks consistently spent more time eating mash $(3.5 \%)$ than LW chicks $(2.8 \%)$. Within days, however, the difference was significant only on day 6 (fig 4 a). Overall the percentage of I chicks eating mash $(2.5 \%)$ was less than for $R$ chicks $(3.8 \%)$ while values for I and $R$ chicks were similar for yolk (1.9 and $2.0 \%$ ) (fig $4 b$ ).

On days 2 and 6,1 chicks rested less than $\mathrm{R}$ chicks. Percentages on day 2 were $78 \%$ for I and $84 \%$ for $\mathrm{R}$ chicks. For Day 6 the same percentages were 66 and $76 \%$ which mirror values for standing (fig $5 b$ ). Similarly, between-line comparisons for standing and resting over all observations during the $7 \mathrm{~d}$ of the experiment showed that HW chicks spent more time standing $(15 \%)$ than LW $(13 \%)$ and less time resting (77 vs $81 \%$ ) (fig $5 a$ ).

\section{Organ size}

At $7 \mathrm{~d}$ of age there were significant line-bytreatment interactions for body, heart, liver, chyme and small intestine (full and empty) weights, but not weights of pancreas or yolk sac. When these traits were expressed per $100 \mathrm{~g}$ body weight the interactions were significant only for small intestine full and chyme. This interaction resulted from a dif- 

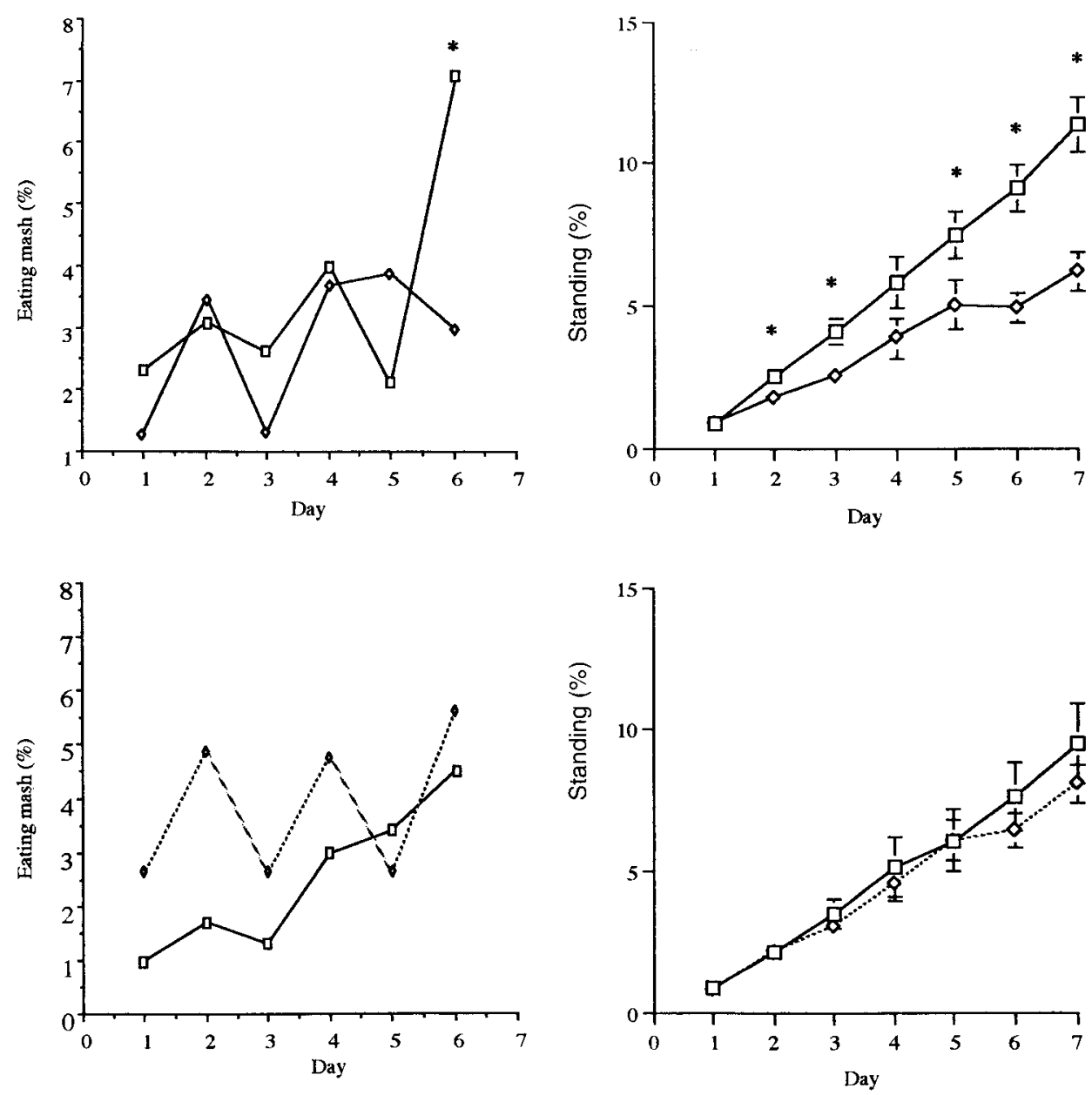

Fig 4. Percentage of time spent eating mash (choice group) by line (top) and by treatment (bottom) during the first week of life. ${ }^{*} P<0.05$. Top: $\square \mathrm{HW} ; \diamond \mathrm{LW}$; bottom: $\square$ intact; $\diamond$ removed.

Fig 5. Percentage of time spent standing by line (top) and by treatment (bottom) during the first week of life. ${ }^{*} P<0.05$. Top: $\square \mathrm{HW}$; $\diamond \mathrm{LW}$; bottom: $\square$ intact; $\diamond$ removed.

ference between lines for RM while RC, IC and IM groups were similar for both lines (table IV). There were no differences between lines or among treatments for heart or liver weights, nor between lines for yolk sac weight. Moreover, IM and IC groups had similar yolk-sac weights. HW chicks

had heavier pancreases and small intestines and longer shanks than LW chicks. Liver and pancreas weights were similar for treatment groups. For I chicks and for R chicks the small intestine was larger for $M$ than $C$ chicks. RM chicks had longer shanks than IC and IM chicks. 


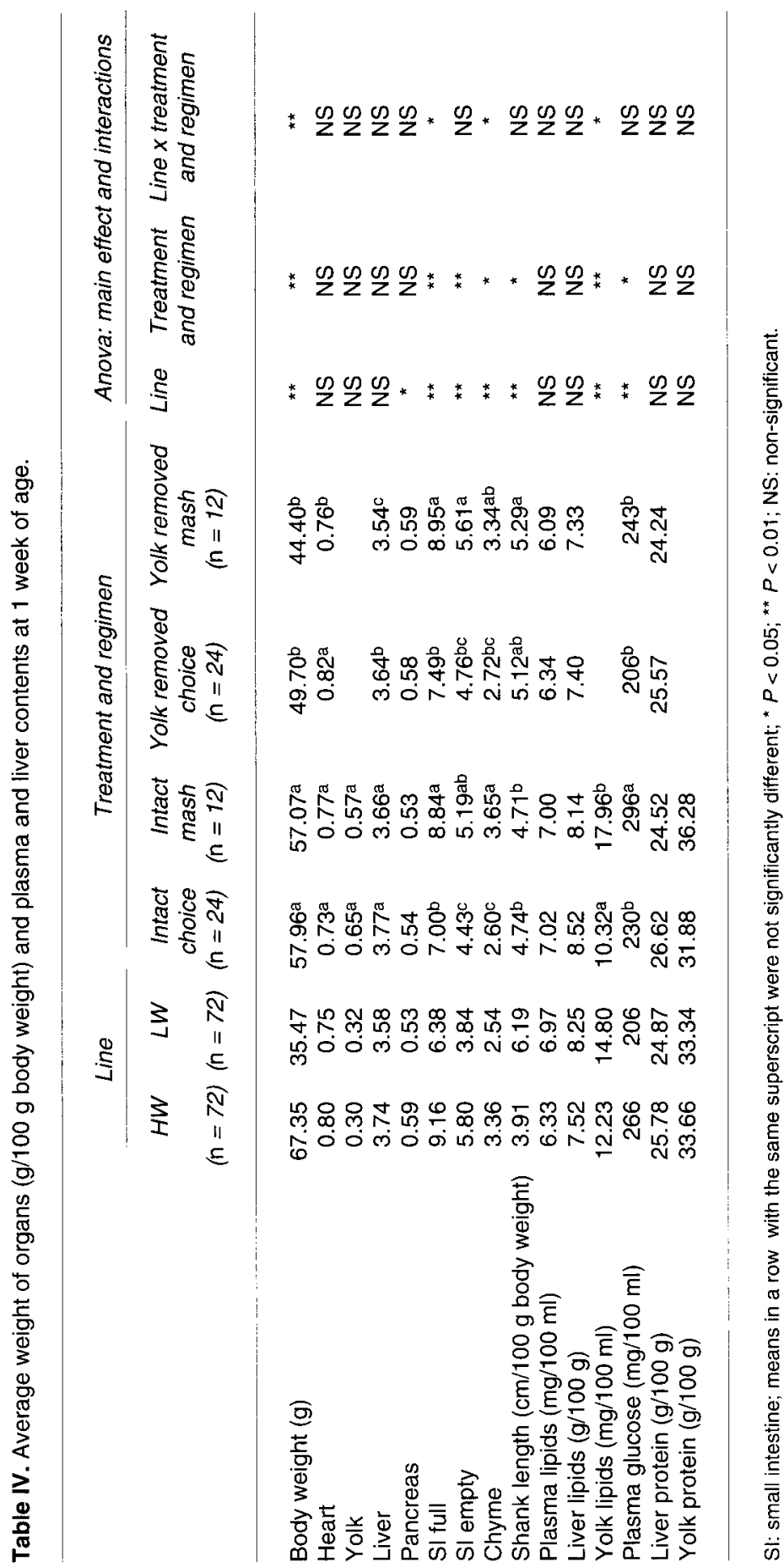




\section{Protein, lipids and glucose in plasma, liver and yolk}

Plasma glucose concentration was higher for HW than LW chicks and for IM chicks than for those in the other groups. Levels of lipids in the plasma and in the liver and protein in liver and in yolk were not affected consistently by line or treatment (table IV). Line LW chicks eating mash had higher levels of yolk lipids than those given a choice of mash and yolk. For the group eating mash only, the level was also higher in LW than HW chicks.

\section{DISCUSSION}

The results obtained in this experiment confirm observations (Nitsan et al, personal communication; Turro et al, 1994) that lines HW and LW differed in their responses to removal of the yolk sac at hatch and that the first $3 d$ after hatch were critical to the chick's development. Growth and feeding behavior varied between treatments and lines. Both yolk-intact and yolk-removed HW chicks ate more food and were heavier than their LW counterparts. This pattern has been observed several times with intact chicks from these lines and can be explained by the selection for body weight which is associated with appetite (Siegel and Wisman, 1966; McCarthy and Siegel, 1983). Moreover, the 2 lines have different ingestion capacities, with the digestive system being more developed during the early post-hatch periods in HW than LW chicks (O'Sullivan et al, 1992b) as confirmed by the larger pancreas and intestine of the HW vs LW observed in the present study.

Feeding motivation is quite different in the 2 lines (eg, Barbato et al, 1980; BoaAmponsen et al, 1991; O'Sullivan et al, 1992b; Noble et al, 1993). Generally, HW chickens were hyperphagic while LW ones were hypophagic with some individuals being anorexic (Burkhart et al, 1983; Zelenka et al, 1988). Such behavior has even been observed at hatch (O'Sullivan et al, 1992a). In the present experiment, in addition to line differences, I chicks consumed more food and gained more weight than those with yolk removed, an observation consistent with those reported for broiler chicks by Murakami et al (1992) and Chamblee et al (1992).

Nitsan et al (1991) suggested that nutrients from the yolk are used in development of the gastrointestinal tract (GIT) of the embryo. It may be hypothesized from our results that this role might continue during the first days after hatch. In contrast to intact chicks, those from which the yolk sac has been removed do not have this high source of nutrients available in order to develop the GIT for a more efficient utilization of exogenous food. This may contribute to retarded growth in those chicks.

Relative to body weight, the GIT was heavier in mash-fed chicks than in those given a choice of yolk and mash. Intact chicks eating only mash ingested greater amounts of food than the other groups, even more than those given a choice between yolk and mash. However, chicks with choice had a very high source of energy and protein from the yolk, so they could reduce the amount of dry matter eaten to balance their diet.

The responses of the chicks in terms of metabolisable energy and protein intake were different from that of total intake and tended to vary according to line and treatment. Because LW chicks consumed a higher percentage of yolk and had lower eating motivation and a smaller GIT than $\mathrm{HW}$ chicks, they might have been limited in the amount of food they ate. It may be assumed that they preferred a higher energy food, such as yolk, and ingested less of the low density diet. Huey et al (1982) observed that HW chickens preferred diets contain- 
ing relatively higher protein and lower energy, while LW ones preferred relatively lower protein and higher energy diets. Thus, the preference for yolk may be linked to an avoidance by LW chicks for carbohydrate contained in the mash diet because their GIT would be inefficient in digesting it during the first few days after hatch.

In intact chickens, Calabotta et al (1983, 1985) found higher levels of plasma lipid and greater lipolytic capacities with mash feeding in LW than in HW chicks. In our experiment, LW chicks also tended to have higher levels of plasma lipid than HW chicks. This difference did not, however, mean that the residual yolk which contained about $35 \%$ fat was digested efficiently by LW chicks.

The responses of chicks to choice feeding are influenced by genetic stock, feeding treatment, and age. By the third day after hatch considerable changes had occurred in the young chick. Nutrients from the residual yolk were essentially utilized (Nitsan et al, 1991; Nir and Levanon, 1993) and the chick had changed from primarily a lipidbased to a carbohydrate-based metabolism with external food sources (Duke, 1984). This change might explain the pattern of reduced yolk intake $5 \mathrm{~d}$ after hatch. The shift from an endogenous to an exogenous feed source was apparently delayed in R chicks. This delay may be because removal of the yolk sac resulted in a delay in the general development of the chick, particularly in the capacity of using exogenous yolk and in functionality of the GIT. Such a delay in development is consistent with the observation of Murakami et al (1992) that removal of residual yolk at hatch resulted in a 2-d delay in growth. In the same way, intact HW chicks increased in growth on day 2 while in $R$ chicks this increase occurred on day 3. Finally, while intact chicks eating mash and those eating mash and yolk had similar growth curves, the exogenous yolk allowed an increase in growth. HW chicks in which the yolk sac was removed did not compen- sate for the lack of the yolk sac by overconsumption of energy or protein.

In the LW line, I chicks ate less than $R$ ones but the percentage of yolk in the diet was higher. $\mathrm{R}$ chicks with choice tended to consume more protein than intact ones. Overconsumption of protein could explain the ability of the LW-R chicks to maintain the same growth rate as that of I chicks eating only mash. Compared to chicks fed only mash, choice feeding of yolk and mash improved the growth of $I$ and $R$ chicks from both lines. Choice feeding, however, only partially compensated for yolk sac removal in $R$ chicks. Differences between lines may have been due to differences in metabolic and/or digestive utilization of the nutrients from the yolk (endogenous and exogenous). Moreover, because the GIT was more developed in I than R chicks from line HW, it may be hypothesized that those chicks were able to utilize endogenous yolk more efficiently than the exogenous yolk to develop their GIT. There may be difficulties in digesting the yolk, which is very high in lipids. It may be possible that endogenous yolk was not digested in the intestine through the yolk stalk but was transported directly to the circulation (Nitsan et al, personal communication).

Development of the GIT was similar in I and $R$ chicks from line $L W$ suggesting that they responded similarly to endogenous and exogenous yolk. Chicks from this line had higher levels of lipids (liver, plasma) than those from the HW line which is consistent with results of Calabotta et al (1985), who observed more extensive lipolysis and lipogenesis in LW than HW chicks. Conversely, $\mathrm{HW}$ chicks had higher levels of glucose in plasma, so they may have digested carbohydrates more efficiently than the LW chicks during the first few days after hatch. Because LW chicks consumed greater amounts of yolk than the HW chicks, and HW chicks consumed more mash than LW ones, perhaps HW chicks had greater capa- 
bilities to digest the carbohydrate part of the diet while LW chicks were more efficient in digestion of lipid. Moreover, LW line chicks presented with a choice reduced their energy intake and maintained protein consumption, as compared with control chicks eating only mash. Those chicks ate less but gained more weight to 4 and $7 d$ of age than controls. Therefore LW chicks were not as efficient as HW chicks in the digestion of the carbohydrate part of the mash while protein may be well digested in both lines. These results may explain why 'exogenous' yolk improved growth even in the HW line chicks. This experiment suggests that yolk residue has a determining role in the initiation of growth (during the first week after hatch) which cannot be compensated by feeding exogenous yolk nutrients in fast growing animals. Nutrition of the very young chick requires further research in relation to the early development of their GIT.

\section{ACKNOWLEDGMENTS}

We are grateful to the Institut National de la Recherche Agronomique (France) which provided financial support to I Turro-Vincent for her stay in the Virginia Polytechnic Institute and State University, and to the Conseil Régional de la Région Centre (France), which supports her by a grant.

\section{REFERENCES}

Barbato GF, Cherry JA, Siegel PB, Van Krey HP (1980) Quantitative analysis of the feeding behavior of four populations of chickens. Physiol \& Behav 25, 885891

Boa-Amponsen K, Dunnington EA, Siegel PB (1991) Genotype, feeding regimen, and diet interactions in meat chickens. 2. Feeding behavior. Poult Sci 70 , 689-696

Brody TB, Cherry JA, Siegel PB (1983) Overfeeding and restriction effects on food and glucose preference in weight-selected lines of chickens. Poult Sci 62 , 2056-2061

Burkhart CA, Cherry JA, Van Krey HP, Siegel PB (1983) Genetic selection for growth rate alters hypothalamic satiety mechanisms in chickens. Behav Genet 13, 295-300

Calabotta DF, Cherry JA, Siegel PB, Gregory EM (1983) Lipogenesis and lipolysis in normal and dwart chickens from lines selected for high or low body weight. Poult Sci62, 1830-1837

Calabotta DF, Cherry JA, Siegel PB, Jones DE (1985) Lipogenesis and lipolysis in fed and fasted chicks from high and low body weight lines. Poult Sci 64, 700-704

Chamblee TN, Brake JD, Schultz CD, Thaxton JP (1992) Yolk-sac absorption and initiation of growth in broilers. Poult Sci 71, 1811-1816

Duke GE (1984) Avian digestion. In: Duke's Physiology of Domestic Animais (MJ Swensen, ed) Cornell Univ Press, Ithaca, NY, 359-366

Dunnington EA, Siegel PB (1985) Long-term selection for 8-week body weight in chickens: direct and correlated responses. Theor Appl Genet 71, 305-313

Dunnington EA, Nir I, Cherry JA, Jones DE, Siegel PB (1987) Growth-associated traits in parental and F1 population under different feeding programs. 3 . Eating behavior and body temperatures. Poult Sci 66 , 23-31

Folch J, Lees M, Stanley HS (1957) A simple method for isolation and purification of lipids from animal tissue. J Biol Chem 226, 497-509

Hestin-Lerner S, Ben Yonah S (1963) A method for blood glucose determination: modification of glucose oxidase method. Bull Res Counc Isr Sec E Exp Med 10, 188-191

Huey DF, Cherry JA, Siegel PB, Denbow DM, Van Krey HP (1982) Self selection of dietary protein and energy by diverse populations of chickens. Nutr \& Behav 1 , 55-64

Kaufman LW, Collier G, Squibb L (1978) Selection of an adequate protein carbohydrate ratio by the domestic chick. Physiol \& Behav 20, 339-344

Leclercq B, Guy G (1991) Further investigations on protein requirements of genetically lean and fat chickens. Br Poult Sci 32, 789-798

MCCarthy JC, Siegel PB (1983) A review of genetical and physiological effects of selection in meat-type poultry. Anim Breed Abstr 51, 87-94

Murakami H, Akiba $Y$, Horiguchi M (1988) Energy and protein utilization in newly hatched broiler chicks. Studies on the early nutrition of poultry. Jpn J Zootech Sci 59, 890-895

Murakami H, Akiba Y, Horiguchi M (1992) Growth and utilization of nutrients in newly hatched chicks with or without residual yolk. Growth Dev \& Aging 56, 75-84

Nir I, Levanon M (1993) Effect of posthatch holding time on performance and on residual yolk and liver composition. Poult Sci 72, 1994-1997

Nir I, Nitsan Z, Ben-Avraham G (1988) Development of the intestine, digestive enzymes and internal organs 
of the newly hatched chick. Nutrition and feed resources. In: Proc 18th World's Poult Congr, Nagoya, Japan 861-864

Nitsan Z, Dunnington EA, Siegel PB (1991) Organ growth and digestive enzyme levels to 15 days of age in lines of chickens differing in body weight. Poult Sci $70,2040-2048$

Noble DO, Dunnington EA, Siegel PB (1993) Ingestive behavior and growth when chicks from lines differing in feed consumption are reared separately or intermingled. Appl Animal Behav 35, 359-368

O'Sullivan NP, Dunnington EA, Larsen AS, Siegel PB (1992a) Correlated responses in lines of chickens divergently selected for 56-day body weight. 1 . Growth, feed intake and feed utilization. Poult Sci 71, 590-597

O'Sullivan NP, Dunnington EA, Siegel PB (1992b) Correlated responses in lines of chickens divergently selected for 56-day body weight. 3 . Digestive enzymes. Poult Sci71, 610-617
Rose SP, Kyriakis I (1991) Diet selection of pigs and poultry. Proc Nutr Soc 50, 87-98

Siegel PB, Wisman EL (1966) Selection for body weight at 8 weeks of age. 6 . Changes in appetite and feed utilization. Poult Sci 45, 1391-1397

Sinurat AP, Balnave D (1986) Free choice feeding of broilers at high temperatures. Br Poult Sci 27, 577584

Turro 1, Dunnington EA, Nitsan Z, Picard M, Siegel PB (1994) Effect of yolk-sac removal at hatch on growth and feeding behavior in lines of chickens differing in body weight. Growth, Dev \& Aging 58, 105-112

Zelenka DJ, Dunnington EA, Cherry JA, Siegel PB (1988) Anorexia and sexual maturity in female White Rock chickens. 1. Increasing feed intake. Behav Genet $18,383-387$

Zoeliner N, Kirsch K (1962) Determination of lipids (micro method) by means of sulfophosphovanillin reaction common to many natural lipids (all known plasma lipids). Zeit Geit Exper Med 135, 545-561 